\title{
Influence of phosphorus nutrition on seed yield and quality of pea (Pisum sativum L.) cultivars across different seasons
}

\author{
Agnieszka Klimek-Kopyra, ${ }^{1}$ Josef Hakl, ${ }^{2}$ Jiri Skladanka, ${ }^{3}$ Joanna Dłużniewska ${ }^{1}$ \\ ${ }^{1}$ Department of Microbiology and Biomonitoring, University of Agriculture, Kraków, Poland; ${ }^{2}$ Department \\ of Forage Crops and Grassland Management, Czech University of Life Sciences, Prague, Czech Republic; \\ ${ }^{3}$ Department of Animal Nutrition and Forage Production, Mendel University in Brno, Brno, Czech Republic
}

\begin{abstract}
Due to the rapid shrinking of supply of mineral nutrients as well as observed weather fluctuations in throughout Europe in recent ten years, sustainable phosphorus fertilisation has become an important aspect of legume cultivation. There is a lack of knowledge about the effect of phosphorus (P) nutrition on the pea seed yield and quality in water poor conditions. This study was conducted to evaluate the seed yield and seed chemical composition of selected pea cultivars in response to the level of P fertilisation and weather conditions across three consecutive years. Redundancy analysis (RDA) was used to assess the proportion of variability of tested variables (seed quality traits) that could be explained by explanatory variables (year, cultivar, fertilisation). Temporary soil drought during flowering stage resulted in a significant increase in yield only after high level of phosphorus application $\left(140 \mathrm{~kg} \mathrm{ha}^{-1}\right)$. This indicates that phosphorus significantly mitigated the effect of water shortage. In a dry year, pea had high concentration of fat and fibre in seeds, while in very humid year the opposite response was observed. RDA analysis proved that year effect explained over 50\% variability, whereas cultivar and $\mathrm{P}$ fertilisation explained only $14.2 \%$ of variability. The effect of $\mathrm{P}$ fertilisation was only marginal $(1.6 \%)$ in comparison with cultivar selection (12.6\%). Interaction of pea cultivars with fertilisation shows a consistent tendency towards increase of crude protein under higher phosphorus doses for cultivars 'Tarchalska' and 'Protecta' whereas opposite tendency was observed for 'Batuta'
\end{abstract}

Correspondence: Agnieszka Klimek-Kopyra, Department of Microbiology and Biomonitoring, University of Agriculture, Aleja Mickiewicza 21, 31-120 Kraków, Poland.

E-mail: agnieszka.klimek@urk.edu.pl

Key words: Legumes; phosphorus; semi drought; yield quality.

Received for publication: 21 February 2019.

Revision received: 25 July 2019.

Accepted for publication: 19 August 2019.

(C) Copyright: the Author(s), 2019

Licensee PAGEPress, Italy

Italian Journal of Agronomy 2019; 14:1411

doi:10.4081/ija.2019.1411

This article is distributed under the terms of the Creative Commons Attribution Noncommercial License (by-nc 4.0) which permits any noncommercial use, distribution, and reproduction in any medium, provided the original author(s) and source are credited. and 'Tinker'. It can be concluded that suitable cultivar selection gives a much greater opportunity to affect pea chemical composition than $\mathrm{P}$ fertilisation.

\section{Introduction}

Deficit of high-quality protein fodder for livestock has been increasing significantly in Europe over the last decade (Annicchiarico, 2017; Watson et al., 2017). This deficit has been associated with unpredictable weather conditions, which constitutes as the important environmental factor limiting the yield of legumes family (Annicchiarico and Iannucci 2008; Farooq et al., 2017). Water deficit impedes the legume growth at all stages, but the flowering and seeds maturity stages are the most sensitive (Barnabas et al., 2008; Samarah et al., 2009). For instance, Klimek-Kopyra et al. (2017) indicated that low temperatures during the first stage of plant development-seedling stage have a great impact on pea productivity. Reports presented by Alqudah et al. (2011) indicate that the reproductive stage is the most critical phase of the plants development as it strongly influences the quality and quantity of the final yield. Authors proved that drought has a significant effect on the chemical composition of cowpea (Farooq et al., 2017), soybean (Bellaloui et al., 2013), common bean (Ghanbari et al., 2013). In soybean severe drought stress during grain filling reduced oil content by up to $12.4 \%$ with a simultaneous decrease in oleic acid content (Farooq et al., 2017). Moreover, drought altered fatty acid composition in soybean, which affected total oil levels, stability of oil and oil composition, especially during seed filling (Bellaloui et al., 2013). Drought induced inhibition of protein biosynthesis is responsible for the loss in quality of grain legume seeds (Farooq et al., 2017). Drought increased acid detergent fibre and neutral detergent fibre concentrations in a forage legumes, but decreased crude protein (CP) concentrations (Liu et al., 2018). Environmental factors alter the composition of legume seeds and only adoption of suitable crop husbandry practices can assist mitigating the changes in quality of seeds. For instance, mineral fertilisation influences the concentration of protein, oil and fatty acid (Israel et al., 2007; Piergiovanni et al., 2017). According to Klimek-Kopyra et al. (2016), the low phosphorus application is a limiting factor in pea plant production. The authors proved that in a dry year an increase of the phosphorus fertilisation rate up to $140 \mathrm{~kg} \mathrm{ha}^{-1}$ improved the physiological processes resulting in better pea yield. Jin et al. (2014) also demonstrated that water use efficiency with adequate phosphorus fertilisation increased the concentration of soluble sugar and phosphorus in drought stresses plants. Although a fair amount of studies reported the impact of drought on various phys- 
iological and biochemical parameters in legumes crops (Farooq et al., 2017; Liu et al., 2018), the influence of weather conditions in interaction with phosphorus application on the pea yield and quality has been rarely evaluated. Therefore, this field study was conducted over 3-year period to evaluate the seed yield and seed chemical composition of pea cultivars in response to level of P fertilisation and weather across three consecutive years.

\section{Materials and methods}

\section{Experimental locality}

A 3-year field experiment (2013-2015) was conducted on Haplic Phaeozem in the Experimental station of Agriculture University in Prusy, near Kraków (47 $24^{\prime}$ N lat., $7^{\circ} 19^{\prime}$ E long., 300 $\mathrm{m}$ a.s.1.). The soil characteristics were as follows: $\mathrm{pH}$ 5.6, content of $\mathrm{P}_{2} \mathrm{O}_{5} 9.4 \mathrm{mg} 100 \mathrm{~g}^{-1}, \mathrm{~K}_{2} \mathrm{O} 11.1 \mathrm{mg} 100 \mathrm{~g}^{-1}$. A two-factor field experiment was established in a randomised block design. The first factor was the level of phosphorus application with simple super phosphate $18 \%$ in three different levels $\left(\mathrm{P} 0=0 \mathrm{~kg} \mathrm{ha}^{-1} \mathrm{P}_{2} \mathrm{O}_{5} ; \mathrm{P} 70\right.$ $=70 \mathrm{~kg} \mathrm{ha}^{-1} \mathrm{P}_{2} \mathrm{O}_{5} ; \mathrm{P} 140=140 \mathrm{~kg} \mathrm{ha}^{-1} \mathrm{P}_{2} \mathrm{O}_{5}$ ). The second factor was the cultivars. Six different cultivars viz. 'Protecta', 'Tarchalska', 'Batuta', 'Mecenas', 'Tinker' and 'Model' were used in the study. The plot size was $10 \mathrm{~m}^{2}$. The pre-crop each year was a winter wheat. Before sowing, mineral fertilisers were applied and the soil was treated with cultivator. The nitrogen, as a fertiliser in ammonium nitrate form (34\%) was applied at the starter rate of 30 $\mathrm{kg} \mathrm{ha}^{-1}, 100 \mathrm{~kg}$ of potassium (potassium salt - 57\%). Sowing was carried out in the first decade $\left(10^{\text {th }}\right.$ and $\left.12^{\text {th }}\right)$ of April in 2013 and 2014 years, and in last decade $\left(21^{\text {st }}\right)$ of March in 2015 year. Weeds were controlled twice using linuron at $1.25 \mathrm{~L} \mathrm{ha}^{-1}$ at the seedling stage and bentazon at $3 \mathrm{~L} \mathrm{ha}^{-1}$ and flowering stage of plant development. Bifentryna $0.2 \mathrm{~L}_{\text {at }} \mathrm{ha}^{-1}$ was applied against pea aphid. The harvest was carried out in the first decade $\left(7^{\text {th }}, 5^{\text {th }}, 10^{\text {th }}\right)$ of August each year.

\section{Weather conditions}

The weather data were collected from the Weather Station located in the Experimental Station in Prusy, near Kraków (47 $24^{\prime}$ $\mathrm{N}$ lat., $7^{\circ} 19^{\prime} \mathrm{E}$ long., $300 \mathrm{~m}$ a.s.1.) (Table 1 ). The analysis of weather conditions was based on the monthly air temperatures and total precipitation during the growth and development of the plants. In 2013, March was humid, April was dry (seed sowing), June (bud formation-flowering) was extremely wet, while July and august were extremely dry (seeds setting). In 2014 April and may (seedling stage) were wet with frequent rainfall. June was optimal for plant (buds formation). July and August (flowering and seeds setting) were very wet. In 2015 April and May were wet whilst June, July were very dry. In 2013 and 2015 drought was recorded during the seed setting and maturity stage (July-August).

\section{Sampling and measurement}

The yield was assessed in the senescence stage from whole plot in each year. After the harvest, seed samples from each plot were collected, dried at $70^{\circ} \mathrm{C}$ for $48 \mathrm{hs}$, and weighed. The dried samples were reassembled and ground to pass through a $1-\mathrm{mm}$ screen. Crude nutrients and crude fibre contents were determined by the Weende method (AOAC, 1995) and acid detergent fibre (ADF) and neutral detergent fibre (NDF) concentrations were measured according to standard laboratory procedures for forage quality analysis (Van Soest, 1991). The crude protein (CP) content was determined with using Kjeltec 2300 (Foss, Denmark) and the crude fibre (CF) content was determined by using fibre analyser (ANKOM, USA). The Fat content was determined Soxhlet (AOAC, 1995).

\section{Statistical analysis}

Effect of year, cultivar and $\mathrm{P}$ fertilisation was evaluated by three-way ANOVA with interaction. Significant differences between means were reported using the Tukey HSD test at $\alpha=$ 0.05. All these analyses were carried out using the software Statistica 10 (Statsoft). Redundancy analysis (RDA) was used to perform three main analyses $\left(\mathrm{A}_{1-3}\right)$ for the variance partitioning procedure (Ter Braak and Šmilauer, 2002), with assessment of the proportion of variability of tested variables (seed quality traits) that could be explained by explanatory variables (year, cultivar, fertilisation). The option of 'centre and standardise' by dependent variables was used in RDA. The statistical significance of the first and all of the other constrained canonical axes was determined by the Monte Carlo permutation test (499 permutations). All ordination analyses were performed in the program CANOCO 4.5 (Ter Braak and Šmilauer, 2002). An ordination biplot of redundancy analysis (RDA) was created in CanoDraw (Microcomputer Power, USA) for graphical visualisation of the relationship between seed chemical composition (dependent variables) and cultivar $\times$ P fertilisation interaction (explanatory variables) where year was used as covariate.

\section{Results}

Based on the statistical analysis, significant impact of weather conditions, phosphorus fertilisation and type of cultivars on seed yield was found (Table 2). The highest yield of seeds $\left(412.3 \mathrm{~g} \mathrm{~m}^{-2}\right)$ was gained in the wet year of vegetation (2014), while water shortage during maturity stage in 2013 and 2015 significantly decreased yielding (by $12.4 \%$ and $11.7 \%$, respectively). The level of phosphorus application had an impact on seed yield, since significantly higher yield (406.5 $\mathrm{g} \mathrm{m}^{-2}$ ) was obtained after phosphorus application. However, the application of the highest dose of phosphorus (140 kg ha ${ }^{-1}$ ) was justified in drought years (2015), which was confirmed by significant interaction between years and fertilisation.

The crude protein was influenced by weather conditions and cultivars. Phosphorus had a limited effect on this parameter. The course of the weather in 2014 negatively affected protein concentration, resulting in a very low protein accumulation in seeds (207.6 $\left.\mathrm{g} \mathrm{kg}^{-1} \mathrm{DM}\right)$. Among the cultivars, particularly edible cultivars varied in crude protein concentration. The cultivar 'Tarchalska' had the lowest crude protein concentration (208.8 g

Table 1. Weather conditions in successive months of the growing season in each year.

\begin{tabular}{|c|c|c|c|c|c|c|}
\hline Years & March & April & May & June & July & August \\
\hline \multicolumn{7}{|c|}{ Temperature $\left({ }^{\circ} \mathrm{C}\right)$} \\
\hline 2013 & -0.9 & 8.9 & 14.2 & 17.5 & 19.5 & 19.0 \\
\hline 2014 & 6.5 & 10.3 & 13.9 & 16.3 & 20.4 & 17.5 \\
\hline 2015 & 4.6 & 8.7 & 13.0 & 17.5 & 20.6 & 21.5 \\
\hline \multicolumn{7}{|c|}{ Rainfall (mm) } \\
\hline 2013 & 32.3 & 20.1 & 98.8 & 213.1 & 27.2 & 25.7 \\
\hline 2014 & 47.0 & 43.0 & 107 & 80.0 & 183 & 142 \\
\hline 2015 & 36.3 & 42.2 & 103.8 & 35.8 & 42.4 & 69.1 \\
\hline
\end{tabular}


$\mathrm{kg}^{-1} \mathrm{DM}$ ), while cultivar 'Protecta' gained the highest amount of crude protein $\left(221 \mathrm{~g} \mathrm{~kg}^{-1} \mathrm{DM}\right)$.

Fat concentration in pea were significantly affected by weather conditions, cultivar type and phosphorus fertilisation (Table 2). Indeed, a higher concentration of fat was found in the wet year of vegetation period (2014). Among the compared cultivars, the highest concentration of fat $\left(12.8 \mathrm{~g} \mathrm{~kg}^{-1} \mathrm{DM}\right)$ was obtained by the cultivar 'Model', while the lowest level had cultivar 'Mecenas' (10.8 $\left.\mathrm{g} \mathrm{kg}^{-1} \mathrm{DM}\right)$. In the dry year, during maturity stage, significant effect of phosphorus fertilisation on fat concentration in seeds was observed. Simultaneously with increasing of fertilisation, the concentration of fat in 'Batuta' and 'Mecena' cultivars increased.

Crude fibre concentration in pea were hardly affected by weather conditions, fertilisation and cultivar type. The highest crude fibre values in pea seeds were achieved in very dry year (2015), while lover value was observed in very wet year (2014). Higher concentration of crude fibre was gained in treatments with phosphorus application. Among the cultivars, 'Mecenas' in particular had significantly lower crude fibre concentration in seeds. For this cultivar, crude fibre values ranged from $54.9 \mathrm{~g} \mathrm{~kg}^{-1} \mathrm{DM}$.

Acid detergent fibre (ADF) content in seeds was significantly dependent on weather conditions and cultivars type, while phosphorus fertilisation had a significant and strong impact on the acid detergent fibre content in weather-varying years. In years characterised by dry periods during maturity stage (2013 and 2015), high phosphorus fertilisation significantly increased acid detergent fibre concentration in most tested cultivars. Reverse phenomena were observed in the wet year (2014), where phosphorus fertilisation resulted in a significant reduction of this parameter. The average content of acid detergent fibre ranged between 74-91 $\mathrm{g} \mathrm{kg}^{-1} \mathrm{DM}$. The highest value of acid detergent fibre was obtained in the dry year (2015), the lowest in the very wet year (2014). Among the compared cultivars, the fodder cultivar cumulated the higher amount of acid detergent fibre.

The neutral detergent fibre (NDF) content in seeds was significantly dependent on all testing factors. In the dry year, during maturity stages (2015), the highest level of phosphorus fertilisation significantly increased neutral detergent fibre concentration in seeds of the mostly tested cultivars. It has been observed that the efficiency of phosphorus fertilisation was related to the duration of the drought. In 2013 short-term drought, which was observed mainly during seed maturity, resulted in a significant increasing of neutral detergent fibre concentration in seeds after the lower phosphorus application. On the other hand, in 2015, when the water shortage was observed from flowering stage till seeds maturity stage, the application of a higher dose of phosphorus resulted in a significant increase of neutral detergent fibre. The average value of neutral detergent fibre ranged between 165-219 $\mathrm{g} \mathrm{kg}^{-1} \mathrm{DM}$. Among the compared cultivars, the edible pea cultivar 'Tarchalska' cumulated the highest amount of neutral detergent fibre in seeds.

The contribution of tested factors to total variability of seed

Table 2. Analysis of variance of the effect of year, cultivar and fertilisation on the qualitative traits and seed yield.

\begin{tabular}{|c|c|c|c|c|c|c|c|}
\hline Factor & \multicolumn{5}{|c|}{ Pea qualitative traits (g kg-1 DM) } & Ash & $\begin{array}{c}\text { Seed yielc } \\
\mathrm{g} \mathrm{m}^{-2}\end{array}$ \\
\hline \multicolumn{8}{|c|}{ Year $(\mathrm{df}=2.90)$} \\
\hline 2013 & $221.3^{\mathrm{a}}$ & $9.8^{\mathrm{a}}$ & $56.0^{\mathrm{b}}$ & $76.1^{\mathrm{a}}$ & $146.5^{b}$ & $30.3^{\mathrm{a}}$ & $361.1^{\mathrm{a}}$ \\
\hline 2014 & $207.6^{b}$ & $14.9^{\mathrm{b}}$ & $54.5^{\mathrm{a}}$ & $75.3^{\mathrm{a}}$ & 130.6 & $30.3^{\mathrm{a}}$ & $412.3^{b}$ \\
\hline 2015 & $219.8^{\mathrm{a}}$ & $10.1^{\mathrm{a}}$ & $74.0^{c}$ & $93.8^{\mathrm{b}}$ & 348.8 & $31.8^{\mathrm{b}}$ & $364.2^{\mathrm{a}}$ \\
\hline P-value & $<0.0001$ & $<0.0001$ & $<0.0001$ & $<0.0001$ & $<0.0001$ & $<0.0001$ & 0.003 \\
\hline \multicolumn{8}{|c|}{ Cultivar $(\mathrm{df}=5.90$ ) } \\
\hline Mecenas & $216.4^{\mathrm{ab}}$ & $10.8^{\mathrm{a}}$ & $54.9^{\mathrm{b}}$ & $74.4^{\mathrm{b}}$ & $175.5^{\mathrm{b}}$ & $30.6^{\mathrm{ab}}$ & $398.6^{\mathrm{b}}$ \\
\hline Tinker & $212.3^{\mathrm{bc}}$ & $11.4^{\mathrm{ab}}$ & $60.9^{\mathrm{a}}$ & $80.7^{\mathrm{a}}$ & $202.3^{\mathrm{a}}$ & $31.2^{\mathrm{b}}$ & $416.6^{\mathrm{ab}}$ \\
\hline Protecta & $221.1^{\mathrm{a}}$ & $11.9^{\mathrm{abc}}$ & $60.2^{\mathrm{a}}$ & $80.0^{\mathrm{a}}$ & $187.5^{\mathrm{ab}}$ & $29.6^{\mathrm{a}}$ & $332.7^{\mathrm{a}}$ \\
\hline Tarchalska & $208.8^{c}$ & $12.5^{\mathrm{bc}}$ & $60.9^{\mathrm{a}}$ & $77 . .^{\mathrm{ab}}$ & $202.6^{\mathrm{a}}$ & $29.6^{\mathrm{a}}$ & $364.9^{b}$ \\
\hline Batuta & $216.5^{\mathrm{ab}}$ & $11.5^{\mathrm{ab}}$ & $60.9^{a}$ & $80.2^{\mathrm{a}}$ & $192.3^{\mathrm{ab}}$ & $29.9 \mathrm{ab}$ & $339.0^{\mathrm{a}}$ \\
\hline Model & $219.5^{\mathrm{a}}$ & $12.8^{\mathrm{c}}$ & $61.9^{\mathrm{a}}$ & $88.2^{c}$ & $186.6^{\mathrm{ab}}$ & $33.1^{\mathrm{c}}$ & $423.5^{\mathrm{ab}}$ \\
\hline P-value & $<0.0001$ & $<0.0001$ & $<0.0001$ & $<0.0001$ & $<0.001$ & $<0.0001$ & $<0.0001$ \\
\hline \multicolumn{8}{|c|}{ Fertilisation $(\mathrm{df}=2.90)$} \\
\hline $\mathrm{P0}$ & 215.5 & $11.9^{\mathrm{a}}$ & $58.5^{b}$ & 80.6 & $182.6^{\mathrm{a}}$ & $29.9^{\mathrm{a}}$ & $353.9^{\mathrm{a}}$ \\
\hline P1 & 216.8 & $11.4^{\mathrm{a}}$ & $60.5^{\mathrm{a}}$ & 79.3 & $188.3^{b}$ & $31.1^{\mathrm{ab}}$ & $377.2^{\mathrm{ab}}$ \\
\hline P2 & 214.9 & $12.2^{b}$ & $60.9^{\mathrm{a}}$ & 80.7 & $202.5^{c}$ & $30.9^{b}$ & $406.5^{b}$ \\
\hline P-value & 0.383 & 0.013 & $<0.0001$ & 0.633 & $<0.0001$ & 0.002 & 0.007 \\
\hline \multicolumn{8}{|c|}{ Interaction } \\
\hline $\mathrm{Y} \times \mathrm{C}$ & 0.508 & 0.078 & $<0.0001$ & 0.228 & $<0.0001$ & $<0.0001$ & 0.027 \\
\hline$Y \times F$ & 0.898 & 0.011 & 0.002 & $<0.0001$ & $<0.0001$ & 0.915 & $<0.0001$ \\
\hline $\mathrm{C} \times \mathrm{F}$ & 0.075 & 0.067 & 0.254 & 0.653 & 0.099 & 0.870 & 0.900 \\
\hline
\end{tabular}

Letters express statistical differences among years, cultivars and phosphorus fertilisation treatments (Tukey test, $\alpha=0.05$ ); $\mathrm{P} 0=0 \mathrm{~kg}_{\text {ha }}{ }^{-1} \mathrm{P}_{2} \mathrm{O}_{5} ; \mathrm{P} 70=70 \mathrm{~kg}$ ha- 1 P2 $\mathrm{O}_{5} ; \mathrm{P} 140=140 \mathrm{~kg}$ ha ${ }^{-1} \mathrm{P}_{2} \mathrm{O}_{5}$. $\mathrm{DM}$, dry matter; $\mathrm{CP}$, crude protein; CF, crude fibre; ADF, acid detergent fibre; NDF, neutral detergent fibre. 
chemical composition was investigated and the results of RDA are summarised in Table 3. First, the multivariate analysis $\left(\mathrm{A}_{1}\right)$ investigated the contribution of year, cultivar and $\mathrm{P}$ fertilisation to pea seed quality. In the analysis, the tested factors explained $69.7 \%$ of the variability of seed quality (all canonical axes). After separation of year effect, variation in cultivar and $\mathrm{P}$ fertilisation explained $14.2 \%$ whilst interaction cultivar $\times \mathrm{P}$ fertilisation explained $16.5 \%$ of variability $\left(\mathrm{A}_{2}\right)$. All of these analyses were statistically significant $(\mathrm{P}=0.002)$. In the third analysis $\left(\mathrm{A}_{3}\right)$, cultivar and $\mathrm{P}$ fertilisation separately explained 12.6 and $1.6 \%$ of the variability, respectively. As with $\mathrm{A}_{1}$ and $\mathrm{A}_{2}$, all these analyses were statistically significant $(\mathrm{P}<0.042)$.

The relationship among seed chemical traits and external factors are illustrated in the ordination biplot of RDA (Figure 1). The most important first (horizontal) canonical axis represents the higher content of ash, ADF, and CP on right side where fodder cultivar 'Model' is clearly separated from other cultivars. The second (vertical) axis represents mainly an inverse relationship between crude protein and fat where cultivars 'Mecenas' and 'Protecta' were separated from 'Tinker' and 'Tarchalska'. Interaction with fertilisation shows consistent tendency towards increase of crude protein under higher phosphorus doses for cultivars 'Tarchalska' and 'Protecta' whereas a contrasting tendency was observed for 'Batuta' and 'Tinker'. 'Model' and 'Mecenas' show inconsistent trend. This interaction was independent on ash and acid detergent fibre (ADF) content.

\section{Discussion}

In the present experiment, year was found to be the most important factor, explaining $50 \%$ of variability of seed chemical composition. In the absence of sufficient knowledge of pea from previous literature the results are considered in relation to factors affecting the seed yield and quality of other legume seed crops, e.g., soybean. Appearance of water stress during ripening stage (2013 and 2015) had relevant impact on crude protein and crude fibre (acid detergent fibre, neutral detergent fibre) content in seed, since increases were observed in both these parameters.

Our findings are partly confirmed by Farooq et al. (2017), who suggested that in control conditions during early vegetation stage and maturity, the phospholipid fraction of lipids in soybean shoots and roots is significantly lowered by drought stress. In an experiment conducted by Ghanbari et al. (2013a), drought reduced $\mathrm{N}$ content in seeds and hence total protein in seeds of common bean.
A considerable reduction in seed $\mathrm{N}$ and protein content was noted in bean cultivars subjected to drought during pod filling (Ghanbari et al., 2013b). Our research shows different results. In dry years, drought contributed to a significant increase of the protein content in seeds. This finding has an explanation in He and Dijkstra (2014) research, whose findings of negative relationships between effect sizes of above-ground biomass and plant nitrogen suggest that with large reductions in plant biomass, plant nitrogen may increase in response to drought stress. The authors suggest that with less soil moisture, plants respond by growing more root biomass (and roots' absorptive surface) relative to shoot biomass (Lambers et al., 2008; He et al., 2017), which in combination with more concentrated available forms of $\mathrm{N}$ in the soil may result in higher aboveground $(\mathrm{N})$ under severe drought stress. In our study we observed that water shortage at the beginning of plant growth significantly decrease fat content.

Bellaloui et al. (2013) partly confirmed our study, with the finding that drought altered fatty acid composition in soybean, which in turn affected total oil levels, stability of oil and oil composition especially during seed filling. Similar findings presented Nikolopolou et al. (2007). The authors have shown that the fat content was higher under well distributing the re-wetting cycle.

Küchenmeistera et al. (2013), proved that duration of drought stress decided the nutritive value of perennial legumes. Moderate stress has no impact on crude protein, crude fibre fractions (NDF and ADF), while strong drought stress significantly reduces these nutrients in legumes fodder. Fibre concentration is generally influenced by many interacting factors such as genotypes, environmental conditions (drought, temperature, photoperiod, etc.) or availability of nutrients (Fulkerson et al., 2007). These results are in agreement with our own findings. The highest value of ADF was obtained in the dry year (2015), while the lowest was obtained in the very wet year (2014). Farooq et al. (2017) partly confirmed our findings since they demonstrated that hemicellulose contents of soybean shoots or roots rose under drought levels.

There were also differences among cultivars, because our results show that cultivars contributed to $13 \%$ of explained variability response in seed quality. The crude protein, fat, crude fibre fractions varied within cultivars. Among edible pea cultivars ('Tarchalska', 'Protecta', 'Mecenas' and 'Batuta') the difference was from 2.8 to $2.2 \mathrm{~g} \mathrm{~kg}^{-1} \mathrm{DM}$, for fat difference was from 10.8 to $12.5 \mathrm{~g} \mathrm{~kg}^{-1} \mathrm{DM}$, while for crude fibre the difference was from 60.6 to $54.9 \mathrm{~g} \mathrm{~kg}^{-1}$. However, Turk and Albayrak (2012) did not confirm that cultivars differed in soil content. Semi-leafless as well as leafed cultivars obtained similar value of crude fibre and crude protein.

Table 3. Results of redundancy analyses investigating effect of explanatory variables on pea seed chemical composition.

\begin{tabular}{|c|c|c|c|c|c|}
\hline Analysis & Explanatory variables & Covariate & $\%$ ax.1 (all) & F 1 (all) & P 1 (all) \\
\hline$A_{1}$ & $\begin{array}{l}\text { Year, cultivar, } \\
\text { P-fertilisation }\end{array}$ & - & $\begin{array}{c}45.3 \\
(69.7)\end{array}$ & $\begin{array}{l}110.9 \\
(34.3)\end{array}$ & $\begin{array}{c}0.002 \\
(0.002)\end{array}$ \\
\hline $\mathrm{A}_{2}$ & $\begin{array}{l}\text { Cultivar, } \\
\text { P-fertilisation } \\
\text { Cultivar } \times \\
\text { P-fertilisation }\end{array}$ & $\begin{array}{l}\text { Year } \\
\text { Year }\end{array}$ & $\begin{array}{c}8.3 \\
(14.2) \\
9.0 \\
(16.5)\end{array}$ & $\begin{array}{c}8.7 \\
(9.0) \\
31.4 \\
(4.3)\end{array}$ & $\begin{array}{c}0.002 \\
(0.002) \\
0.002 \\
(0.002)\end{array}$ \\
\hline $\mathrm{A} 3$ & $\begin{array}{l}\text { P-fertilisation } \\
\text { Cultivar }\end{array}$ & $\begin{array}{l}\text { Year } \\
\text { Year }\end{array}$ & $\begin{array}{c}1.1 \\
(1.6) \\
7.7 \\
(12.6)\end{array}$ & $\begin{array}{c}3.7 \\
(2.6) \\
28.4 \\
(10.7)\end{array}$ & $\begin{array}{c}0.042 \\
(0.012) \\
0.002 \\
(0.002)\end{array}$ \\
\hline
\end{tabular}

$\%$ ax.1 (all), variability of pea seed quality explained by canonical axis 1 or by all axes in brackets; $\mathrm{F} 1$ (all), F statistics for the test of axis 1 or all axes in brackets; $\mathrm{P} 1$ (all), corresponding probability value obtained by the Monte Carlo permutation test ( 499 permutations) for the test of axis 1 or all axes in brackets. 


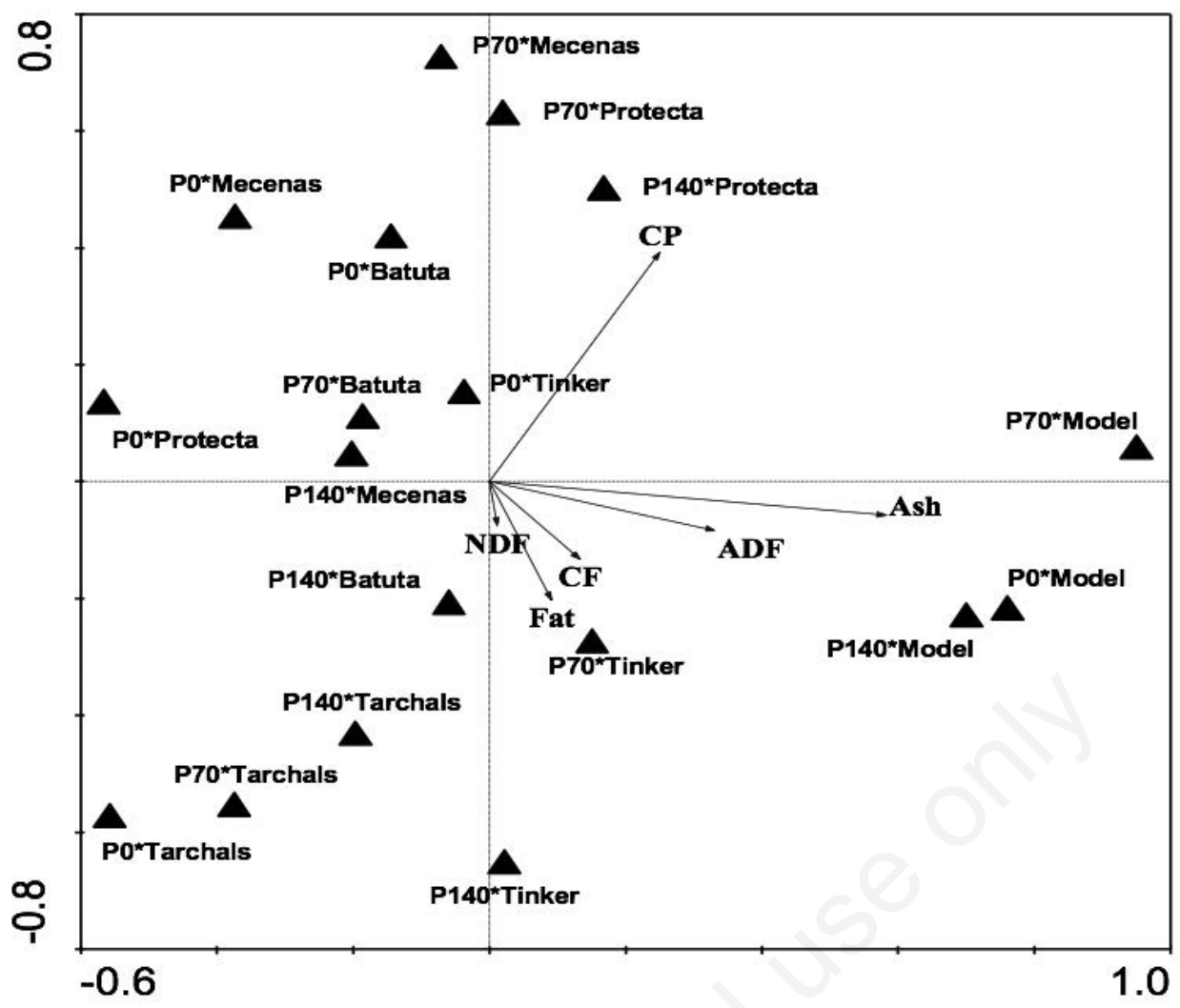

Figure 1. Ordination biplot of redundancy analysis showing the relationship between pea seed chemical composition (dependent variables, arrows) with respect to cultivar effect in interaction with $P$ fertilisation (explanatory variables, triangles, number represent rate of phosphorus, P0-P70-P140 $\mathrm{kg} \mathrm{ha}^{-1} \mathrm{P}_{2} \mathrm{O}_{5}$ ). CF, crude fibre; $\mathrm{CP}$, crude protein; ADF, acid detergent fibre; NDF, neutral detergent fibre.

The results of redundancy analyses investigated the hypothesis that fertilisation represents only $2 \%$ of explained variability response in seed quality. Phosphorus fertilisation had a significant effect only on crude fibre concentration in the seeds. Higher concentration of crude fibre was gained in treatments with phosphorus application. Increase of phosphorus level simultaneously increase crude fibre concentration.

Significant interaction between years and fertilisation was found. This indicates that phosphorus significantly mitigated the effect of water shortage. In dry years, the pea achieved a high concentration of fat and fibre in seeds, while in very humid years the opposite reaction was observed. The use of a high level of phosphorus $\left(140 \mathrm{~kg} \mathrm{ha}^{-1}\right)$ significantly increased the concentration of fat and fibre in the seeds of all tested cultivars, except the fodder one. These findings were also confirmed by Yamane and Skjelvåg (2003), whose showed that phosphorus fertilisation significantly influenced the increase of fat accumulation in pea seeds. He et al. (2017) studied the interactive effects of P fertilisation and drought stress on seed yield and protein concentration in soybean. The authors found that drought stress increased the concentration of $\mathrm{N}$ in shoot and protein in grain. Additionally P alleviated the effect of drought stress on plant growth, $\mathrm{P}$ accumulation and yield. They suggest that application of $\mathrm{P}$ mitigated the adverse effect of drought stress resulting in yield losses and improved grain quality of soybean. Our findings confirmed above scientific suggestion, because the increase of phosphorus application significantly increased yield quality, mainly in dry years.

\section{Conclusions}

Results show that pea chemical composition was significantly influenced by all tested factors, however in different intensity. Year-weather conditions effect explained over 50\% variability where drought stress in year reduced fat and increase protein in seed. Cultivar and P fertilisation explained only $14.2 \%$ of variability. The effect of P fertilisation was only marginal (1.6\%) in comparison with cultivar selection $(12.6 \%)$. P fertilisation increased crude fibre $(\mathrm{CF})$ and slightly increased fat content.

Interaction of fertilisation with cultivars shows tendency in increase of crude protein under higher phosphorus doses for selected cultivars such as 'Tarchalska' and 'Protecta' whereas a contrasting tendency was observed for 'Batuta' and 'Tinker' It can be concluded that suitable cultivar selection gave a much greater opportunity to affect pea chemical composition than $\mathrm{P}$ fertilisation. However, interaction between cultivars and P-fertilisation indicate different response of cultivars to $\mathrm{P}$ application.

\section{References}

Annicchiarico P, 2017. Feed legumes for truly sustainable cropanimal systems. Ital. J. Agron. 12:151-60.

Annicchiarico P, Iannucci A, 2008. Adaptation strategy, germplasm type and adaptive traits for field pea improvement 
in Italy based on variety responses across climatically contrasting environments. Field Crop Res. 108:133-42.

Alqudah AM, Samarah NH, Mullen RE, 2011. Drought stress effect on crop pollination, seed set, yield and quality: alternative farming systems, biotechnology, drought stress and ecological fertilisation. Sustainable Agriculture Reviews. Springer, Dordrecht, The Netherlands.

AOAC. 1995. Official methods of analysis: official method for protein. Method No. 920.87. Association of Official Analytical Chemists, Washington, DC, USA.

Barnabás B, Jäger K, Fehér A, 2008. The effect of drought and heat stress on reproductive processes in cereals. Plant Cell Env. 31:11-38.

Bellaloui N, Mengistu A, Kassem MA, 2013. Effects of genetics and environment on fatty acid stability in soybean seed. Food Nut. Sci. 4:165-75.

Carvalho M, Lino-Neto T, Rosa E, Carnide V, 2017. Cowpea: a legume crop for a challenging environment. J. Sci. Food Agr. 97:4273-84.

Farooq M, Gogoi N, Barthakur S, Baroowa B, Bharadwaj N, Alghamdi S, Siddique KHM, 2017. Drought stress in grain legumes during reproduction and grain filling. J. Agr. Crop Sci. 203:81-102.

Fulkerson WJ, Neal JS, Clark CF, Horadagoda A, Nandra KS, Barchia I, 2007. Nutritive value of forage species grown in the warm temperate climate of Australia for dairy cows: grasses and legumes. Liv. Sci. 107:253-264.

Ghanbari AA, Shakiba MR, Toorchi M, Choukan R, 2013a. Nitrogen changes in the leaves and accumulation of some minerals in the seeds of red, white and chitti beans (Phaseolus vulgaris) under water deficit conditions. Aust. J. Crop Sci. 7:70612.

Ghanbari AA, Mousavi SH, Mousapour Gorgi A, Rao IM, 2013b. Effects of water stress on leaves and seeds of bean (Phaseolus vulgaris L.). Turk. J. Field Crops 18:73-7.

He J, Jin Y, Du YL, Wang T, Turner T, Yang RP, Kadambot H, Siddique M, Li FM, 2017. Genotypic variation in yield, yield components, root morphology and architecture, in soybean in relation to water and phosphorus supply. Front. Plant Sci. 8:111.

Israel DW, Kwanyuen P, Burton JW, Walker DR, 2007. Response of low seed phytic acid soybeans to increases in external phosphorus supply. Crop Sci. 47:2036-46.

Klimek-Kopyra A, Skowera B, Zając T, Grygierzec B, 2016.
Development and production response of edible and forage varieties of pea (Pisum sativum L.) to temporary soil drought under different levels of phosphorus application. Acta Agrobot. 69:1663-76.

Klimek-Kopyra A, Kliszcz A, Ślizowska A, Kot D, 2017. Application of biostimulants infuences shoot and root characteristics of seedlings of winter pea (Pisum sativum L.). Acta Agrobot. 72:1763-71.

Kuchenmeister K, Kuchenmeister F, Kayser M, Wrage-Monning $\mathrm{N}$, Isselstein J, 2013. Influence of drought stress on nutritive value of perennial forage legumes. Int. J. Plant Prod. 7:693710 .

Lambers H, Chapin F, Pons T, 2008. Plant physiological ecology. Springer, New York, USA.

Liu Y, Wu Q, Ge G, Han G, Jia Y, 2018. Influence of drought stress on alfalfa yields and nutritional composition. BMC Plant Biol. 18:1-13.

Nikolopoulou D, Grigorakis K, Stasini M, Alexis MN, Iliadis K, 2007. Differences in chemical composition of field pea (Pisum sativum) cultivars: effects of cultivation area and year. Food Chem. 103:847-52.

Piergiovanni AR, Lioi L, Montesano V, Sarli G, 2017. Comparative evaluation of phosphorus accumulation and partitioning in seeds of common bean (Phaseolus vulgaris L.). Ital. J. Agron. 12:849.

Samarah NH, Alqudah AM, Amayreh JA, McAndrews GM, 2009. The effect of late-terminal drought stress on yield components of four barley cultivars. J. Agr. Crop Sci. 195:427-41.

Ter Braak CJF, Šmilauer P, 2002. CANOCO reference manual and CanoDraw for Windows user's guide: software for canonical community ordination (version 4.5) Microcomputer Power Ithaca.

Turk M, Albayrak S, 2012. Effect of harvesting stages on the forage yields and quality in pea cultivars of differing leaf types. Turk. J. Field Crop. 17:111-4.

Watson CA, Reckling M, Preissel S, Bachinger J, Bergkvist G, Zander P, Murphy-Bokern D, Stoddard FL, 2017. Grain legume production and use in European agricultural systems. Adv. Agr. 144:235-303.

Yamane A, Skjelvåg OA, 2003. Effects of fertiliser phosphorus on yield traits of Dekeko (Pisum sativum var. abyssinicum) under field conditions. J. Agr. Crop Sci. 189:14-20. 